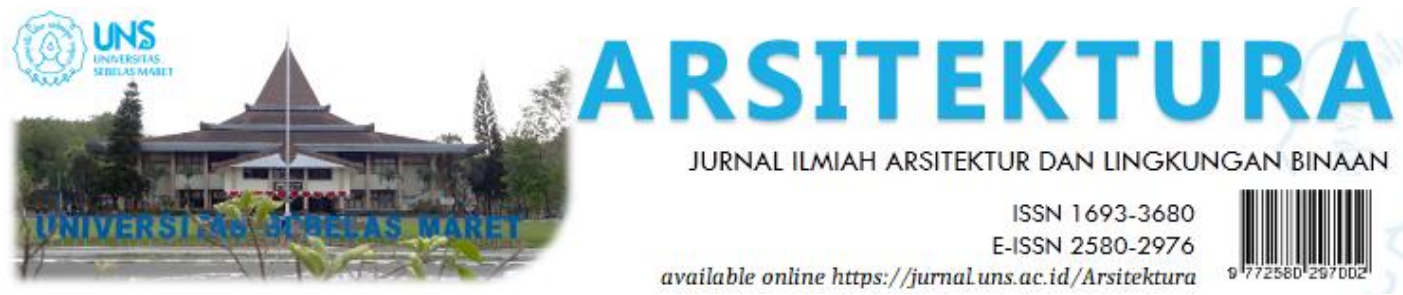

Volume 18 Issue 1 April 2020, pages:140-150

\title{
Implementasi Teori Waktu Dengung Pada Balai Musik Jazz di Surakarta Studi Kasus : Auditorium Dan Jazz Club
}

\section{Implementation of Reverberation Time in Jazz Music Hall Surakarta Case Study : Auditorium And Jazz Club}

\author{
Talisa Audryn ${ }^{1 *}$, Amin Sumadyo $^{2}$, Avi Marlina ${ }^{3}$ \\ Architecture, Engineering Faculty, Sebelas MaretUniversity ${ }^{1 *}$ \\ Email : talisa.madina@yahoo.co.id \\ Architecture, Engineering Faculty, Sebelas MaretUniversity ${ }^{2}$ \\ Architecture, Engineering Faculty, Sebelas MaretUniversity ${ }^{3}$
}

DOI: https://doi.org/10.20961/arst.v18i1.34648

Received: September 21, 2019 Revised: April 24,2020 Accepted: April 27,2020 Available online:April 30, 2020

\begin{abstract}
Surakarta has high interest in the development of music such as Jazz music. This issue can be seen from the existence of the largest Jazz music community in Surakarta that actively organizes regular events named SoJazz. Society. Surakarta also has an annual routine event named Solo City Jazz. However, all of Jazz music events in Surakarta do not have an appropriate place acoustically based on reverberation time. The purpose of this design is to implementing reverberation time in the interior design of the auditorium and jazz club of Jazz Music Hall in Surakarta. According to the planning location in Surakarta, there is a possibility of collaboration between Jazz music and Central Javanese music because the city of Surakarta is famous for traditional performing arts. Beside that, Jazz music and Traditional music also have the same reverberation time range. The method used in this design is quantitative regarding to reverberation time. The result of this design are Auditorium and Jazz Club which are designed with the arrangement of centralized speaker and the application of Heradesign, Thermatex, Plasterboard, cloth, carpet and wood materials in this design. Auditorium designed with hexagonal shape, the distance between spectators and performers is not more than $40 \mathrm{~m}$.
\end{abstract}

Keywords: music hall, jazz music, javanese music, reverberation time.

\section{PENDAHULUAN}

Kota Surakarta memiliki apresiasi dan minat yang tinggi terhadap perkembangan musik di Indonesia salah satunya adalah musik Jazz. Hal ini dapat terlihat dari adanya komunitas Jazz di Surakarta yaitu Solo Jazz Society atau
SoJazz Society yang merupakan komunitas musik Jazz terbesar di Surakarta berdasarkan laman web Bentara Budaya Solo mengenai komunitas Balai Soedjatmoko Solo. Berdasarkan laman instagram SoJazz Society (@solojazzsociety), komunitas musik jazz ini 
memiliki acara mingguan yaitu SoJazz Practice Session dan SoJazz Jam Session.

SoJazz Society sendiri memiliki event rutin setiap 2 bulan sekali yaitu Parkiran Jazz yang dilakukan di Balai Soedjatmoko Slamet Riyadi (Metta, 2018). Parkiran Jazz mencoba mengedukasi masyarakat mengenai musik Jazz melalui pergelaran. Selain event rutin, SoJazz Society beberapa kali tampil pada event Jazz seperti Jazzin Lebaran, Solo City Jazz, Ngayojazz dan beberapa event lainnya (Bentara Budaya Solo, 2018.). Jazzin Lebaran sudah dilakukan sejak tahun 2009 lalu hingga pelaksanaan yang terakhir pada tanggal 29 Oktober 2016 di Lokananta (Dermawan, 2016). Acara ini merupakan salah satu kegiatan yang dilakukan bersama komunitas Balai Soedjatmoko setelah sebelumnya dilakukan pada kawasan Ngarsapura. Pada tanggal 24-25 November 2018, di Surakarta juga akan mengadakan event musik Jazz baru yaitu Road to Mangkunegaran Jazz Festival (Rafiq, 2018). Kegiatan ini disusul dengan acara utama yaitu Mangkunegaran Jazz Festival yang dilakukan pada tanggal 29-30 Maret 2019 yang turut mengundang seniman musik Jazz nasional dan internasional (Edy, 2019).

Selain kegiatan acara musik yang di selenggarakan oleh So Jazz Society, Kota Surakarta juga memiliki acara rutin tahunan yaitu Solo City Jazz. Solo City Jazz diselenggarakan oleh event organizer C-Pro yang berasal dari Jakarta yang memiliki ide sekaligus penyelenggara SCJ (Wardhana, 2016). Ide ini didukung langsung oleh Walikota Solo tahun 2009, yaitu Joko Widodo. Penyelenggaraannya dibantu oleh Mataya Art dan Heritage local-Organizer yang focus pada event budaya. Solo city Jazz mengundang musisi Jazz nasional ternama di nusantara seperti Tompi, Fariz RM hingga Nona Ria sebagai bintang tamu. Event ini merupakan event yang terbuka untuk umum dan tidak berbayar.

Adakalanya penyelenggaraan Solo City Jazz ini cukup mengganggu aktifitas masyarakat Solo lainnya. Seperti pada tahun 2018, Solo City Jazz mengambil latar pada pasar Gede solo, sehingga area jalan sekitar pasar gede terpaksa harus ditutup selama 6 jam (Suharsih, 2018). Selain itu, antusiasme masyarakat Solo terhadap pergelaran musik Jazz yang dilakukan secara gratis ini cukup membuat meledaknya pengunjung yang datang. Pada Solo City Jazz, pengunjung yang datang diberikan kursi penonton. Beberapa kali kursi penonton kurang mengakomodasi jumlah penonton yang datang sehingga banyak penononton yang berdiri dan menghalangi penonton lainnya dibagian belakang (Fitriani, 2017). Hal ini terjadi salah satunya pada penyelenggaraan Solo City Jazz pada tahun 2017.

Indonesia memiliki balai musik ataupun aula musik seperti balai recital kertanegara dan aula simfonia Jakarta sebagai salah satu wadah bagi pencinta musik. Kedua bangunan ini lebih terfokuskan dalam mendukung aliran musik klasik, namun belum terdapat balai musik untuk musik Jazz. Jawa tengah sendiri saat ini belum memiliki gedung pertunjukan musik khusus musik Jazz. Namun, beberapa kota di Jawa Tengah sudah memiliki komunitas musik Jazz. Dalam rangka mendukung berkembangnya musik Jazz di Jawa Tengah maka dibutuhkan sebuah ruang yang mendukung.

Berkembangnya musik Jazz di Jawa Tengah khususnya di kota Surakarta tentu membutuhkan wadah serta fasilitas yang memadai bagi penyelenggara acara serta penggemar musik Jazz. Dengan demikian, Balai Musik Jazz diperlukan untuk di bangun di kota Surakarta.

Kota Surakarta merupakan kota Budaya yang terkenal dengan seni pertunjukannya. Kota Surakarta tentu membutuhkan wadah untuk apresiasi seni musik Jawa Tengah. Besar kemungkinan pada masa yang mendatang, akan terjadi kolaborasi antara musik Jazz dan musik Jawa Tengah sehingga menciptakan jenis musik baru. Selain itu, Kota Surakarta sendiri memiliki peraturan daerah no 8 tahun 2016 tentang bangunan gedung yang mengatur mengenai persyaratan penampilan bangunan. Dengan demikian, Balai Musik Jazz ini juga diharapkan dapat mewadahi apresiasi musik budaya Jawa Tengah serta memberikan tampilan bangunan dengan unsur lokalitas.

Sebuah perencanaan ruang musik yang dapat digunakan untuk musik Jazz dan musik 
Tradisional Jawa Tengah secara bersamaan ini dapat direncanakan dengan prinsip akustik ruang untuk dua jenis musik tersebut. Hal ini juga didasari dengan adanya kesamaan pada kebutuhan waktu dengung kedua jenis musik tersebut. Dibutuhkan jangkauan waktu dengung dengan range yang sama sehingga dapat menghasilkan sebuah ruangan yang dapat digunakan untuk kegiatan Musik Jazz dan juga Musik Tradisional.

Artikel ini bertujuan untuk merancang bangunan Balai Musik Jazz di Surakarta dengan konsep akustik interior berdasarkan waktu dengung ruang yang mampu menunjang segala kegiatan yang dibutuhkan pengguna.

Informasi serta data yang berkaitan dengan objek yang diteliti, belum ada penelitian yang sama dengan penelitian ini dari segi judul ataupun fokus penelitian pada pendekatan dengan keguanaan ruang yang sama. Pada penelitian "Penerapan Sistem Akustik pada Ruang Auditorium Balai Sidang di Surakarta" Pandu Kartiko dkk (2018), penulis menggunakan volume ruang sebesar 41.539,92 $\mathrm{m}^{3}$ dengan kegunaan ruang untuk balai sidang. Penelitian ini menggunakan waktu dengung sebesar $1,18 \mathrm{~s}$ agar dapat mencapai titik ideal dari akustik ruangnya. Pada penelitian lainnya dengan judul "Solo Music dengan Penerapan Sistem Akustik" oleh Daniel Yanuar dkk (2015), yang melakukan penelitian terkait ruang musik dengan penerapan akustika ruang di kota Surakarta namun belum khusus musik Jazz.

\subsection{Akustik Ruang}

Jenis musik pada dasarnya terbagi menjadi 2 jenis yaitu musik diatonik dan musik pentatonik. Musik diatonik merupakan musik yang menggunakan 7 nada standar (Dictionary, 2010). Jenis musik ini biasanya tidak dihasilkan melalui alat musik tradisonal di Indonesia. Musik Jazz sebagai salah satu aliran musik diatonic, merupakan hasil proses akulturasi nada yang murni seperti asalnya. Musik Jazz membutuhkan sistem akustik ruang yang menghasilkan suara dengan jelas. Musik pentatonik merupakan musik yang menggunakan 5 nada perk oktaf, nada yang digunakan adalah nada pertama, kedua, ketiga, kelima dan keenam dalam skala diatonik (Dictionary, 2010). Di Indonesia, alat musik dengan skala petatonis dapat ditemukan salah satunya pada alat musik gamelan. Musik yang dihasilkan dari musik petatonis seperti musik tradisional daerah.

Akustik Ruang dalam sebuah ruang musik pertunjukan berdasarkan Doelle (1990) dipengaruhi oleh 3 hal yaitu ruang fisik, tata speaker serta penerapan material penyerap pada interior bangunan. Adapun prinsip akustik ruang tersebut adalah sebagai berikut:

\section{Ruang Fisik}

Pengaturan tata ruang pada auditorium musik Jazz, terikait dengan kekerasan bunyi maka, jarak maksimum antar penonton dengan sumber bunyi antara 20-40 m. Sumber bunyi harus memiliki ketinggian antara $60-90 \mathrm{~cm}$. Pemiringan lantai disarankan $>20^{\circ}$. Area penonton ditempatkan dengan maksimal sudut $45^{\circ}$.

Menurut Doelle (1990:58) menyebutkan bahwa nilai volume per tempat duduk penonton yang direkomendasikan untuk gedung pertunjukan serbaguna minimal $5.1 \mathrm{~m}^{3}$ ( $\mathrm{m}$ cubic).

Bentuk ruang yang tepat juga harus dipertimbangkan karena akan mempengaruhi kualitas bunyi. Setiap bentuk ruang tentu mempengaruhi suara yang terdengar secara berbeda-beda.

\section{Penataan Speaker}

Dalam rangka memaksimalkan akustik pada ruang pertunjukan, dibutuhkan loudspeaker. Sistem peletakan speaker terbagi menjadi 2 jenis yaitu terpusat, dan tersebar (Latifah, 2015). Speaker terpusat cocok untuk ruang petunjukan musik sedangkan speaker tersebar cocok untuk auditorium dan cinema.

\section{Material Penyerap}

Sebuah syarat akustik ruang musik Jazz membutuhkan tingkat kualitas akustik yang jernih. Hal ini dapat dimaksimalkan dengan memperbanyak elemen penyerap pada ruangan. Elemen penyerap bunyi memiliki bahan serta koefisien serap yang berbeda-beda. Elemen yang dapat membantu penyerapan bunyi dapat berupa lapisan permukaan dinding, lantai, langit-langit, bahan tirai, lapisan tempat duduk, karpet serta udara dalam ruang. 
Penentuan material penyerap yang digunakan dapat dihasilkan dengan perhitungan waktu dengung yang sesuai dengan musik pentatonic dan diatonik. Pengendalian dengung pada sebuah perancangan akustik sehingga dapat menghasilkan tingkat kejernihan yang dibutuhkan, diatur dengan besaran standar yang disebut waktu dengung atau reverberation time (RT) (Doelle L., 1990). Waktu dengung dapat dihitung dengan persamaan :

$R T=\frac{0,16 \mathrm{~V}}{\mathrm{~A}}$.

Dari rumus sabine diatas, RT merupakan Reverberation time atau waktu dengung dengan satuan detik (s). 0,16 merupkan angka koefisien, $\mathrm{V}$ merupakan ukuran volume ruangan dalam $\mathrm{m}^{3}$ serta $\mathrm{A}$ merupakan luas total dari penyerapan ruang atau jumlah luas material dikali dengan koefisien serap material tersebut dalam sabine $\mathrm{m}^{2}$.

Berdasarkan penelitian psycho dan physio akustik pada musik angklung pentatonic, menunjukan bahwa waktu dengung preferensi untuk musik angklung merupakan 0.8-1.2 detik (Sudarsono, 2012). Akustik ruang pada musik Jazz dan musik tradisional memiliki range waktu dengung yang menyerupai.

Dalam rangka mengontrol waktu dengung pada sebuah sistem akustik, Elemen yang dapat membantu penyerapan bunyi dapat berupa lapisan permukaan dinding, lantai, langit-langit, bahan tirai, lapisan tempat duduk, karpet serta udara dalam ruang. Setiap bahan material memiliki frekuensi penyerapan bunyi yang berbeda-beda. Waktu dengung ditentukan berdasarkan volume ruangnya.

Kondisi waktu dengung ruang pada saat kondisi dipenuhi oleh pengunjung dan tidak dipenuhi oleh pengunjung harus sama atau mendekati (Aditya dkk, 2015). Bahan material kayu setingkat lebih rendah daya serapnya dibandingkan manusia, sedangkan material busa setingkat lebih tinggi daya serapnya. Kualitas serap yang digunakan setidaknya harus memiliki elemen kayu ataupun busa.

\section{METODE}

Metode perencanaan dan perancangan Balai Musik Jazz di Surakarta dilakukan dengan cara analisis data secara kuantitatif dengan simulasi. Penelusuran teori penelitian sebagai pertimbangan dilakukan dengan cara melakukan studi literatur mengenai kebutuhan akustik sebuah ruang yang digunakan untuk bermain musik sesuai standar. Hasil literatur kemudian diterapkan dalam desain Balai Musik Jazz sesuai dengan kebutuhan penerapan ruang akustik khususnya musik Jazz dan musik Tradisional. Studi literature juga dilakukan guna mencari strategi pengendalian waktu dengung sehingga menghasilkan tingkat kejernihan yang dibutuhkan dalam sebuah ruang musik, diatur dengan besaran standar waktu dengung yang diterapkan dalam perancanngan.

Penelitian diawali dengan penentuan model simulasi, yakni untuk memilih model simulasi yang dilakukan sebagai pendekatan kriteria akustik pada ruang yang direncanakan. Pendekatan dilakukan cara perhitungan nilai waktu dengung berdasarkan data ruang yang dibutuhkan dan menghasilkan angka sabine yang mempengaruhi kebutuhan jenis material hingga luasan material pada ruang.

Perencanaan dan perancangan Balai Musik Jazz di Surakarta menggunakan metode kualitatif dilakukan untuk melakukan analisis kebutuhan akustik ruang pada sebuah ruang musik. Analisis untuk tata ruang pertunjukan ini dilakukan berdasarkan Mediastika (2005). Analisis dilakukan dengan cara menyesuaikan kebutuhan dalam tata ruang yang direncanakan khususnya music Jazz dengan standar kebutuhan ruang fisik dari hasil literatur. Analisis kebutuhan tata ruang secara fisik ini meliputi lingkar sudut, jarak maksimum, kemiringan tempat duduk hingga bentuk ruang.

Analisis dilanjutkan dengan kajian penggunaan alat bantu penguat suara untuk mendukung kebutuhan elektroakustik dari ruang yang berupa penggunaan speaker. Kebutuhan akustik dalam ruang disesuaikan berdasarkan jenis pertunjukannya yaitu pertunjukan seni musik Jazz sehingga dilakukan pertimbangan dari beberapa jenis penataan speaker. Hasil pertimbangan yang 
berupa jenis penataan speaker kemudian menjadi kriteria penggunaan speaker dalam ruang.

Selanjutnya, analisis yang bersifat kuantitatif dilakukan sebagai pendekatan nilai simulasi dalam perancangan. Hal ini akan mempengaruhi kebutuhan jenis material penyerap dalam ruang beserta luasan material yang di butuhkan dalam ruang. Kebutuhan material penyerap, diterapkan pada perencanaan dan perancangan ruang Auditorium serta Jazz Club pada Balai Musik Jazz berdasarkan waktu dengung ruangnya hingga menghasilkan kebutuhan material penyerap (Mediastika, 2005).

Perhitungan kebutuhan material diawali dengan rincian kebutuhan ruang berdasarkan penggunanya dan menghasilkan volume ruang. Rincian kebutuhan ruang kemudian dimasukan ke dalam perhitungan dengan menggunakan rumus waktu dengung (RT). Perhitungan juga dilakukan dengan menggunakan waktu dengung $(R T)$ musik Jazz dan waktu dengung (RT) musik Tradisional Jawa Tengah pada rumus Sabine (Doelle, 1990). Perhitungan ini menggunakan data waktu dengung (RT) yang dibutuhkan, volume ruang (V) sesuai perencanaan serta total luas penyerapan ruang berdasarkan materialnya (A).

Perhitungan menghasilkan kebutuhan luas material penyerap. Hasil perhitungan divalidasi dengan Room Calculator Acoustic. Room Calculator Acoustic merupakan sebuah alat bantu simulasi angka serta luasan material yang dapat melakukan perhitungan terkait kebutuhan waktu dengung sesuai dengan jenis material yang direncanakan. Room Calculator Acoustic dapat bekerja dengan cara memasukan angka berupa volume ruang dan luasan serta jenis materialnya yang kemudian dikalkulasikan dalam mencapai suatu angka waktu dengung. DIN 18041 merupakan sebuah penelitian terkait kebutuhan akustik ruang yang dilakukan oleh Christian Nocke dari Jerman. DIN 18041 ini digunakan sebagai standar kalkulasi dalam perhitungan ini.

Analisa material yang berdasarkan waktu dengung menghasilkan kriteria desain ruang yang kemudian diinterpretasikan menjadi sebuah desain interior Auditorium dan Jazz Club pada Balai Musik Jazz.

\section{HASIL DAN PEMBAHASAN}

Pembahasan dilakukan berdasarkan buku Akustika Bangunan oleh Mediastika (2005) tentang akustik ruang dalam sebuah ruang pertunjukan. Akustik dalam ruang pertunjukan dipengaruhi oleh :

\subsection{Fisik Ruang Pertunjukan}

Berdasarkan teori dari Doelle (1990), penempatan area tempat duduk terbaik bagi penonton untuk dapat mendengar serta melihat suatu pertunjukan yaitu ditempatkan pada area longidtudinal dengan sudut sebesar $45^{\circ}$ dan lingkar sudut maksimal sebesar $135^{\circ}$. Jarak yang dapat diterapkan pada sebuah ruang musik merupakan $20 \mathrm{~m}$ untuk suara terbaik dan $40 \mathrm{~m}$ maksimum dari panggung untuk mendapatkan view terbaik.

Pada penerapan desain Balai Musik Jazz yang direncanakan, desain ruang auditorium memiliki tempat duduk dengan lingkar sudut samping maksimal dari titik tengah panggung sebesar $45^{\circ}$. Ruang ini direncanakan akan menggunakan sistem elektroakustik sehingga perlu diperhatikan jarak pandang terbaik. Jarak tempat duduk penonton direncanakan dalam desain terjauh merupakan sebesar 40 meter dari panggung agar penyaji pertunjukan dapat terlihat dan terdengar dengan jelas. Ilustrasi peletakan tempat duduk tersebut dapat dilihat pada gambar 1.

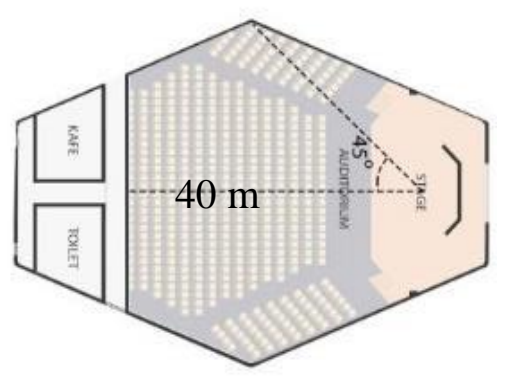

Gambar 1. Lingkar sudut tempat duduk penonton maksimum dan jarak panggung ke tempat duduk.

Tempat duduk dibuat dengan kemiringan $30^{\circ}$, sehingga dapat memberikan garis pandang yang baik dan dapat menampung pantulan bunyi langsung dari lantai panggung (Indrani, 2004). Dengan demikian, ruang Balai Musik Jazz menggunakan kemiringan tempat duduk sebesar $30^{\circ}$ sesuai yang direkomendasikan 
dalam rangka menciptakan view yang baik dari panggung.

Bentuk ruang heksagonal memungkinkan untuk terpilih karena ruang musik Jazz dan musik Tradisional membutuhkan tingkat kejernihan suara yang tinggi. Ruang heksagonal dapat menghasilkan tingkat waktu dengung yang singkat.

\subsection{Penataan Speaker}

Menurut Latifah (2015), terdapat 3 jenis speaker secara umum yang dapat diterapkan pada sebuah ruang pertunjukan musik yaitu terpusat, menyebar dan keduanya. Masingmasing jenis penataan speaker memiliki fungsi yang berbeda-beda.

Bangunan balai musik Jazz pada auditorium dan Jazz Club merupakan sebuah ruang pertunjukan musik tanpa balkon. Penggunaan sistem speaker terpusat merupakan sistem speaker yang baik bagi sebuah ruang musik tanpa balkon merupakan sistem speaker terpusat. Ruang ini dapat menggunakan sistem speaker terpusat dengan ilustrasi sumber suara yang dapat dilihat pada gambar 2 .

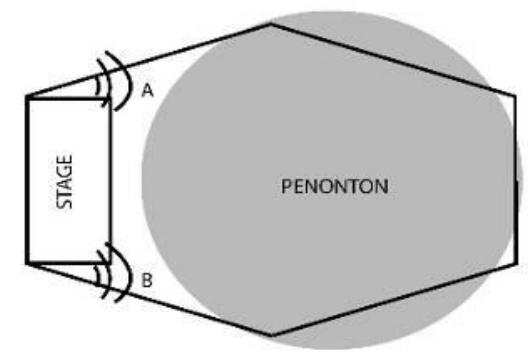

Gambar 2. Penataan Speaker pada Ruang Pertunjukan Musik Jazz

\subsection{Material Penyerap}

Sebuah ruang akustik yang digunakan untuk jenis musik pentatonic memiliki kesamaan kebutuhan akustik ruang diatonik yang dapat terdengar secara jernih dan jelas. Berdasarkan penelitian psycho dan physio akustik pada musik angklung pentatonic, menunjukan bahwa waktu dengung preferensi untuk musik angklung merupakan 0.8-1.2 detik (Sudarsono, 2012).
Akustik ruang pada musik Jazz dan musik tradisional memiliki range waktu dengung yang menyerupai. Hal ini membuat ruangan Auditorium musik Jazz dapat digunakan sebagai pementasan musik Jazz dan juga musik tradisional.

Penggunaan material dengan treatment khusus ini digunakan dalam perencanaan dan perancangan ruang auditorium musik Jazz dan $J a z z$ Club. Pemilihan material penyerap pada perencanaan ini menggunakan 2 tahap. Tahap pertama adalah menggunakan perhitungan waktu dengung sebagai dasar pemilihan material.

Tahap kedua adalah melakukan pengujian menggunakan room acoustic calculator yang didasari oleh DIN 18041 untuk mendapatkan hasil apakah RT dapat dihasilkan dengan spesifikasi material tersebut. Room Calculator Acoustic merupakan sebuah alat bantu simulasi angka serta luasan material yang dapat melakukan perhitungan terkait kebutuhan waktu dengung sesuai dengan jenis material yang direncanakan. Room Calculator Acoustic dapat bekerja dengan cara memasukan angka berupa volume ruang dan luasan serta jenis materialnya yang kemudian dikalkulasikan dalam mencapai suatu angka waktu dengung. DIN 18041 merupakan sebuah penelitian terkait kebutuhan akustik ruang yang dilakukan oleh Christian Nocke dari Jerman. DIN 18041 ini digunakan sebagai standar kalkulasi dalam perhitungan ini.

Secara umum, ruang akustik pada musik angklung pentatonic memiliki waktu dengung 0,8-1,2s (Sudarsono, 2012). Ruang musik Auditorium direncanakan dengan waktu dengung $0,5-1,1$ sec berdasarkan olume ruangnya (Doelle L, 1972). Dari teori tersebut, maka dapat disimpulkan bahwa akustik ruang pada musik Jazz dan musik tradisional memiliki range waktu dengung yang menyerupai. Berdasarkan waktu dengung tersebut dilakukan perhitungan terkait kebutuhan material pada masing-masing elemen. Hasil perhitungan dari rumus waktu dengung menghasilkan kriteria desain material pada ruang Auditorium dan ruang Jazz Club. 
Pada ruang auditorium, memiliki kebutuhan kapasitas 750 orang dengan volume minimum per orang $5,1 \mathrm{~m}^{3}$. Maka dari itu, volume ruang yang dibutuhkan minimum $3.821 \mathrm{~m}^{2}$. Dengan volume tersebut, maka dibutuhkan waktu dengung frekuensi tengah sebesar $0,9 \mathrm{~s}$. Dengan menggunakan rumus waktu dengung (RT), maka:

$R T=\frac{0,161 \mathrm{~V}}{\mathrm{~A}}$

$0,9=\frac{0,161 \times 3.821}{\mathrm{~A}}$

$A=\frac{615,2}{0,9}$

$A=683,534$ sabine $\mathrm{m}^{2}$

Sehingga luas total sabine yang dibutuhkan dalam ruang minimal sebesar 683,534 sabine $\mathrm{m}^{2}$.

Tabel 1. Hasil analisis kebutuhan material ruang Auditorium

\begin{tabular}{|c|c|c|c|c|}
\hline $\begin{array}{l}\text { Bagia } \\
\text { n }\end{array}$ & Jenis & $\begin{array}{l}\text { Sumbe } \\
\mathbf{r}\end{array}$ & Luas & $\mathbf{A}$ \\
\hline $\begin{array}{l}\text { Plafon } \\
\text { d }\end{array}$ & $\begin{array}{l}\text { Plaster Board } \\
\text { Margin }\end{array}$ & $\begin{array}{l}\text { DIN } \\
18041 \\
\end{array}$ & $595 \mathrm{~m}^{2}$ & 0,13 \\
\hline & $\begin{array}{l}\text { Thermatex } \\
\text { Sonic }\end{array}$ & $\begin{array}{l}\text { DIN } \\
18042\end{array}$ & $\begin{array}{l}122 \\
\text { pcs }\end{array}$ & 1,1 \\
\hline Lantai & $\begin{array}{ll}\text { Karpet } & \text { berat } \\
\text { diatas } & \text { karet } \\
\text { busa } & \\
\end{array}$ & Egan & $395 \mathrm{~m}^{2}$ & 0,39 \\
\hline Kursi & Kursi Kain & Egan & $450 \mathrm{~m}^{2}$ & 0,57 \\
\hline $\begin{array}{l}\text { Dindin } \\
\mathrm{g}\end{array}$ & $\begin{array}{l}\text { Heradesign } \\
\text { fine } 15, \mathrm{TCH} \\
=15 \mathrm{~mm}\end{array}$ & $\begin{array}{l}\text { DIN } \\
18041\end{array}$ & $\begin{array}{r}307.2 \\
\mathrm{~m}^{2}\end{array}$ & 0,2 \\
\hline \multicolumn{3}{|c|}{ Total Sabine } & \multicolumn{2}{|c|}{$\begin{array}{r}\mathbf{6 8 3 , 5 3 4} \text { sabine } \\
\mathrm{m}^{2}\end{array}$} \\
\hline
\end{tabular}

Kebutuhan material pada plafond merupakan Plaster Board Margin dengan luasan $595 \mathrm{~m}^{2}$ dan Thermatex Sonic element sebanyak 122 pcs. Material lantai menggunakan karpet berat diatas karet busa dengan luasan $395 \mathrm{~m}^{2}$. Material pada kursi menggunakan bahan kain sebanyak 750 kursi. Material dinding menggunakan material Heradesign sebesar $307.2 \mathrm{~m}^{2}$. Jenis material auditorium Balai Musik Jazz yang sudah ditentukan kemudian diuji dengan Room Calculator Acoustic yang menggunakan dasar DIN 18041. Room

Calculator Acoustic merupakan sebuah alat bantu simulasi angka serta luasan material yang dapat melakukan perhitungan terkait kebutuhan waktu dengung sesuai dengan jenis material yang direncanakan. Room Calculator Acoustic dapat bekerja dengan cara memasukan angka berupa volume ruang dan luasan serta jenis materialnya yang kemudian dikalkulasikan dalam mencapai suatu angka waktu dengung. DIN 18041 merupakan sebuah penelitian terkait kebutuhan akustik ruang yang dilakukan oleh Christian Nocke dari Jerman. DIN 18041 ini digunakan sebagai standar kalkulasi dalam perhitungan ini.

Pengujian dilakukan dengan memasukan data material yang digunakan pada ruang beserta dengan luasannya. Hasil dari kalkulasi akustik ini berupa grafik waktu dengung yang dihasilkan. Waktu dengung yang dihasilkan dapat terlihat pada titik $500 \mathrm{~Hz}$ dengan $\mathrm{g}$ aris berwarna biru. Garis berwarna biru menunjukan waktu dengung pada tingkat frekuensi tertentu pada sebuah ruang dengan furniture. Pada grafik, berdasarkan material yang telah ditentukan, penggunaan furniture dan jumlah pengunjung, maka dihasilkan waktu dengung sebesar 0,9 pada frekuensi 500 $\mathrm{Hz}$ sesuai dengan yang dibutuhkan (gambar $3)$.

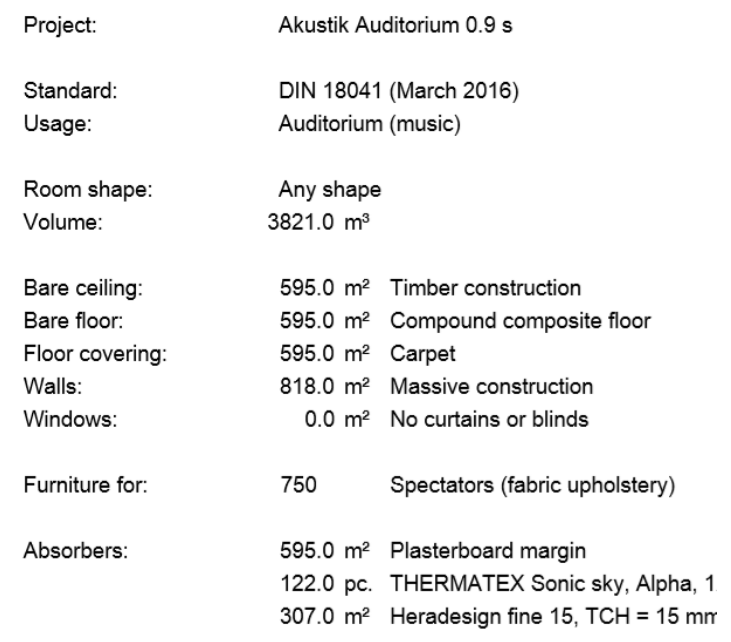

(a)

Gambar 3. a). Data Material Pengujian 


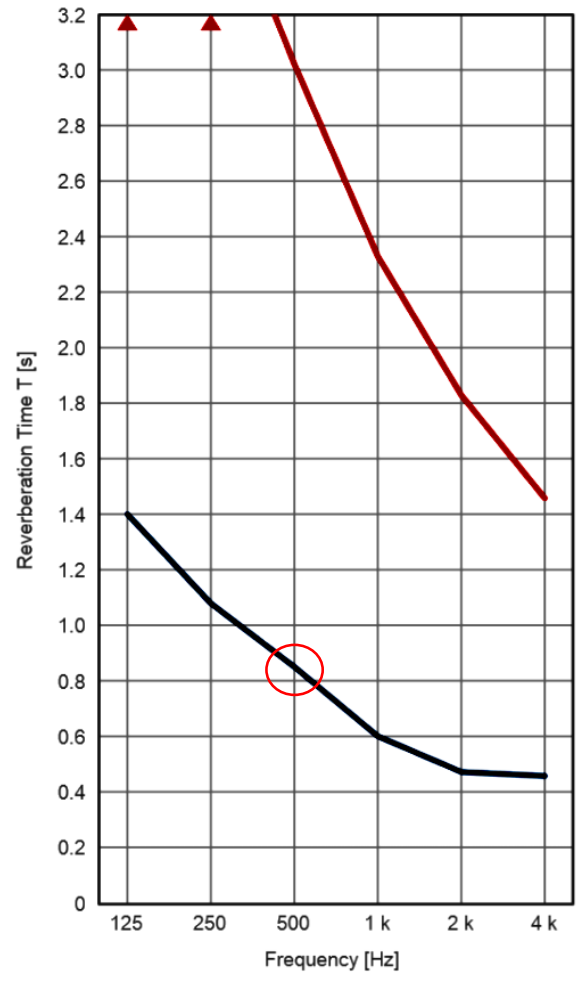

Without abs., without furn., without peop. With abs., with furn., with peop.

(b)

Gambar 3. b). Grafik waktu material auditorium Sumber : knaufamf.com

Material yang telah ditentukan kemudian diinterpretasikan kedalam sebuah desain Auditorium Balai Musik Jazz dengan hasil desain serta rincian material sebagai berikut (gambar 4) :

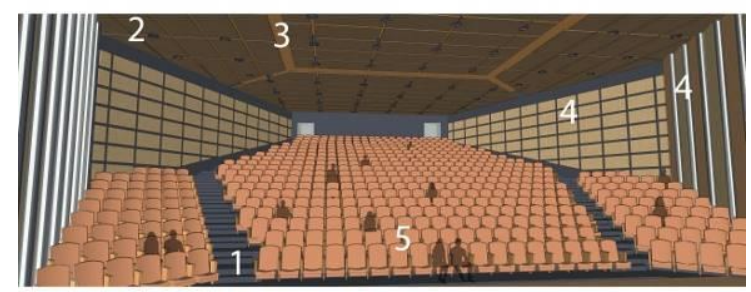

(a)

Gambar 4. a).Desain Auditorium Musik Jazz

1. Karet lapis Karet
$395 \mathrm{~m} 2$

2. Thermatex Sonic $351,36 \mathrm{~m} 2$

\section{Plasterboard Margin $595 \mathrm{~m} 2$}

4. Heradesign

Fine $307 \mathrm{~m} 2$

5. Kursi Kain
60 pcs
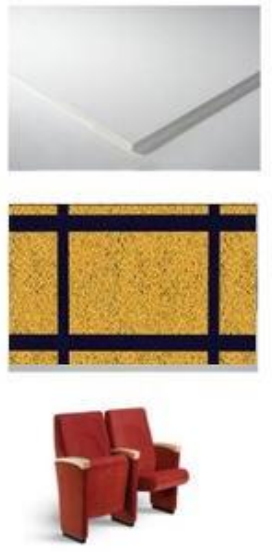

(b)

Gambar 4. b). Pemetaan penerapan material akustik pada ruang Auditorium

Pada ruang Jazz Club, memiliki rancangan dengan kapasitas pengunjung sebanyak 300 orang. Total luas kebutuhan ruang yang direncanakan adalah sebesar $107.25 \mathrm{~m}^{2}$ dibulatkan menjadi $108 \mathrm{~m}^{2}$. Ruang ini direncanakan memiliki tinggi ruang sebesar 5,4 meter sesuai dengan preseden pada Blue Note Jazz. Dengan rincian tersebut, maka volume ruang sebesar $585 \mathrm{~m}^{3}$. dari volume tersebut, maka waktu dengung yang dibutuhkan pada ruangan ini adalah sebesar $0.65 \mathrm{~s}$.

$R T=\frac{0,161 \mathrm{~V}}{\mathrm{~A}}$

$0,65=\frac{0,161 \times 585}{\mathrm{~A}}$

$A=\frac{94,185}{0,65}$

$A=144,9$ sabine $\mathrm{m}^{2}$
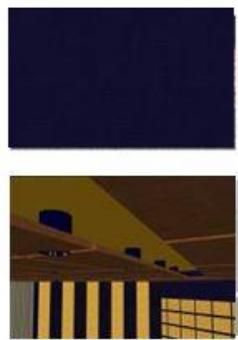

(b) 
Tabel 2. Hasil analisis kebutuhan material ruang Jazz Club

\begin{tabular}{|c|c|c|c|c|}
\hline Bagian & Jenis & Sumber & Luas & $\alpha$ \\
\hline \multirow[t]{2}{*}{ Plafond } & $\begin{array}{l}\text { Heradesign } \\
\text { Baffles }\end{array}$ & $\begin{array}{l}\text { DIN } \\
18041\end{array}$ & $\begin{array}{r}108 \\
\mathrm{~m}^{2}\end{array}$ & 0.19 \\
\hline & $\begin{array}{l}\text { Thermatex } \\
\text { Acoustic }\end{array}$ & $\begin{array}{l}\text { DIN } \\
18041 \\
\end{array}$ & $\begin{array}{r}102 \\
\mathrm{~m}^{2} \\
\end{array}$ & 0.19 \\
\hline Lantai & Linoleum & Doelle & $\begin{array}{r}210 \\
\mathrm{~m}^{2} \\
\end{array}$ & 0.03 \\
\hline \multirow[t]{2}{*}{ Kursi } & Kursi Fabric & Egan & $60 \mathrm{~m}^{2}$ & 0.57 \\
\hline & Kursi Kayu & Egan & $85 \mathrm{~m}^{2}$ & 0.22 \\
\hline \multirow[t]{2}{*}{ Dinding } & $\begin{array}{l}\text { Heradesign } \\
\text { fine } 25, \mathrm{TCH} \\
=115\end{array}$ & $\begin{array}{l}\text { DIN } \\
18041 \\
\end{array}$ & $27 \mathrm{~m}^{2}$ & 0.5 \\
\hline & Curtain & Doelle & $56 \mathrm{~m}^{2}$ & 0,75 \\
\hline \multicolumn{2}{|c|}{ Total Sabine } & \multicolumn{3}{|c|}{144.9 sabine $\mathrm{m}$} \\
\hline
\end{tabular}

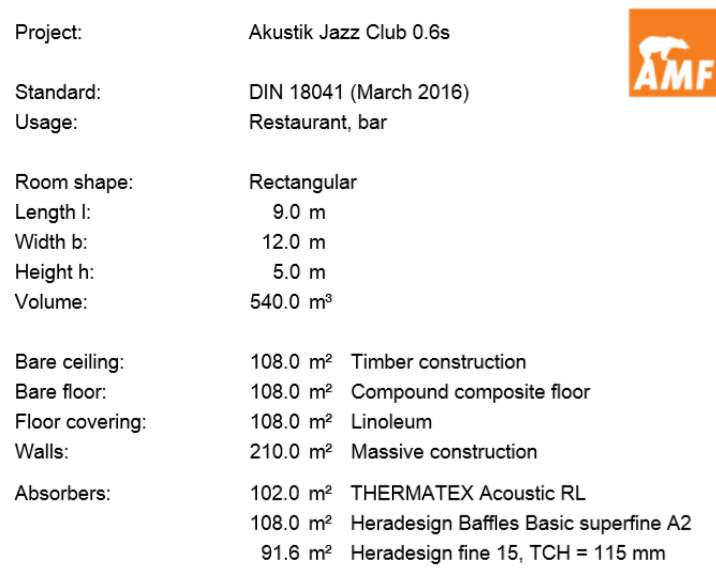

Kebutuhan material pada plafond merupakan Heradesign Baffles dengan luasan $108 \mathrm{~m}^{2}$ dan Thermatex Acoustic element sebanyak $102 \mathrm{~m}^{2}$. Material lantai menggunakan lantai berbahan linoleum dengan luasan $210 \mathrm{~m}^{2}$. Material pada kursi menggunakan bahan kain sebanyak 70 kursi. Material dinding menggunakan material Heradesign sebesar $27 \mathrm{~m}^{2}$ dan material gorden seluas $56 \mathrm{~m}^{2}$.

Jenis material pada Jazz Club ditentukan kemudian diuji dengan Room Calculator yang menggunakan dasar DIN 18041.

Pengujian dilakukan dengan memasukan data material yang digunakan pada ruang beserta dengan luasannya. Hasil dari kalkulasi akustik ini berupa grafik waktu dengung yang dihasilkan. Waktu dengung yang dihasilkan dapat terlihat pada titik $500 \mathrm{~Hz}$ dengan garis berwarna biru. Garis berwarna biru menunjukan waktu dengung pada tingkat frekuensi tertentu pada sebuah ruang dengan furniture. Pada grafik, berdasarkan material yang telah ditentukan, penggunaan furniture dan jumlah pengunjung, maka dihasilkan waktu dengung sebesar 0,6 pada frekuensi 500 $\mathrm{Hz}$ sesuai dengan yang dibutuhkan (lihat gambar 5).

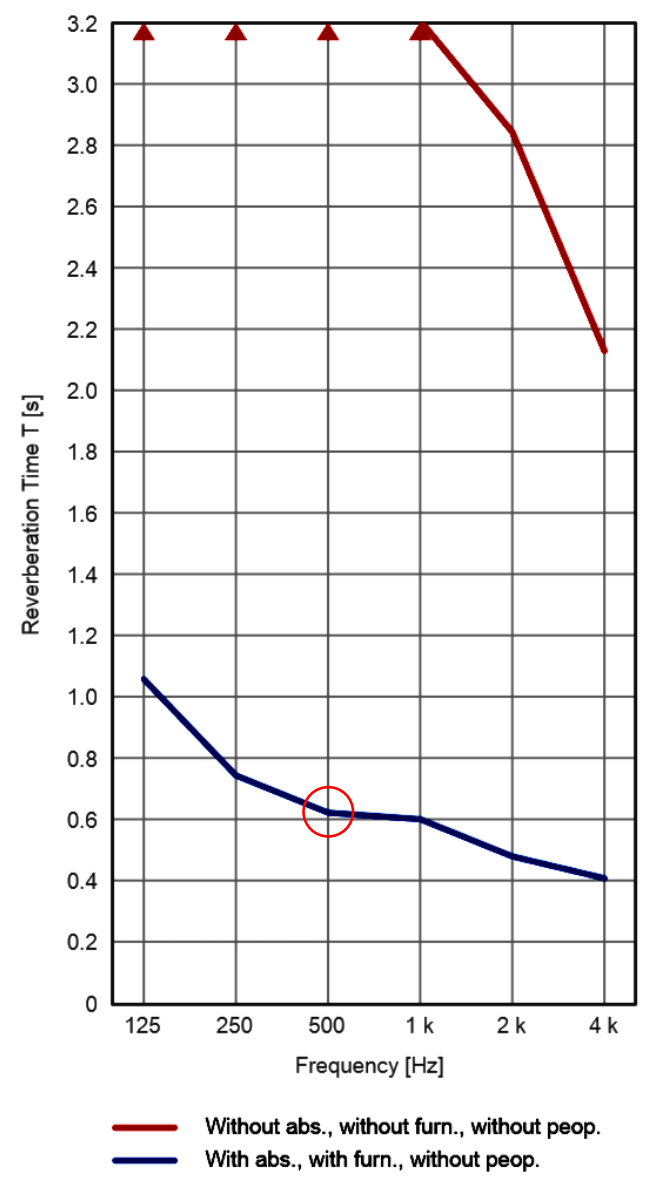

Gambar 5. . Grafik waktu dengung hasil kalkulasi material Jazz Club Sumber : knaufamf.com 
Material yang telah ditentukan kemudian diinterpretasikan kedalam sebuah desain Jazz Club Balai Musik Jazz dengan rincian material sebagai berikut (gambar 6).

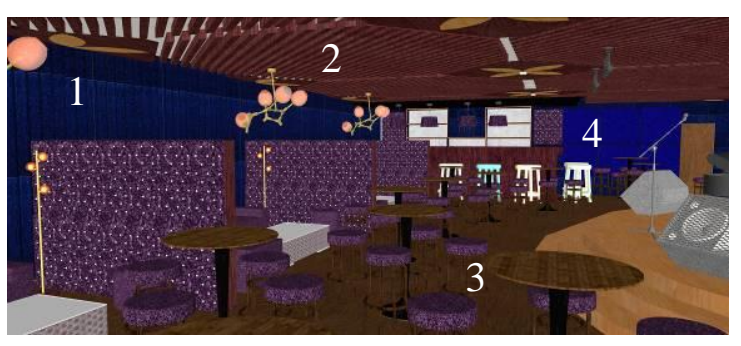

1. Gorden Kain

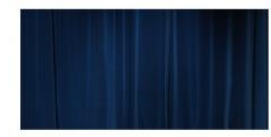

2. Heradesign Baffles $108 \mathrm{~m} 2$

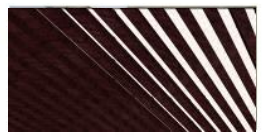

Thermatex Acoustic $\mathrm{RL}, \mathrm{TCH}=200 \mathrm{~mm}$ $102 \mathrm{~m} 2$

\section{Linoleum $210 \mathrm{~m} 2$}
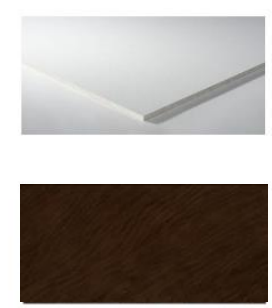

4. Heradesign fine 25 , $\mathrm{TCH}=115 \mathrm{~mm}$

$27 \mathrm{~m} 2$

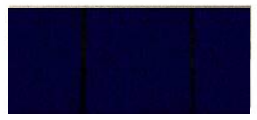

Gambar 6. Pemetaan penerapan material akustik pada ruang Jazz Club

\section{KESIMPULAN}

Balai Musik Jazz di Surakarta direncanakan dengan memaksimalkan penerapan akustik ruang yang berdasarkan waktu dengung ruang. Penerapan ini dilakukan pada bagian interior bangunan seperti ruang Auditorium dan ruang Jazz Club. Penerapan akustik ruang dilakukan berdasarkan teori Doelle (1990) tentang akustik dalam sebuah ruang musik pertunjukan dan dijadikan sebagai strategi desain. Teori Doelle (1990) meliputi pengaruh dari ruang fisik, penempatan speaker dan juga penerapan material.
Ruang fisik meliputi peraturan perencanaan tempat duduk dengan lingkar sudut samping maksimal $45^{\circ}$. Jarak maksimum diterapkan 40 $\mathrm{m}$ dari panggung ke penonton. Kemiringan tempat duduk penonton yang dibuat sebesar $30^{\circ}$ sesuai yang direkomendasikan dengan bentuk ruang auditorium menggunakan bentuk ruang heksagonal. Penempatan speaker pada ruang Auditorium dan Jazz Club menggunakan sistem speaker terpusat.

Penerapan material pada ruang juga mempengaruhi tingkat akustik pada ruangan. Ruang Auditorium dengan fungsi musik Jazz (diatonik) dan musik Tradisional (pentatonik) memiliki waktu dengung ruang (RT) yang berbeda-beda jangkauannya. Pada Auditorium dengan volume $3.821 \mathrm{~m}^{3}$, dibutuhkan waktu dengung sebesar $0,9 \mathrm{~s}$. Waktu dengung ini sesuai dengan kebutuhan waktu dengung musik Tradisional (pentatonik) berdasarkan preferensi musik angklung yang berada pada jangkauan 0,8-1,2 s. Maka dari itu, ruang Auditorium dapat digunakan sebagai wadah musik Jazz serta musik Tradisional pada angka waktu dengung $0,9 \mathrm{~s}$.

Dari perhitungan waktu dengung, maka dihasilkan kebutuhan material pada ruang Auditorium yang sudah diuji dengan Room Calculator akustik dengan dasar DIN 18041. Hasilnya, ruang Auditorium diberi treatment akustik berupa seperti penggunaan plafond yang berupa Plaster Board Margin dengan luasan $595 \mathrm{~m}^{2}$ dan Thermatex Sonic element sebanyak 122 pcs. Material lantai menggunakan karpet berat diatas karet busa dengan luasan $395 \mathrm{~m}^{2}$. Material pada kursi menggunakan bahan kain sebanyak 750 kursi. Material dinding menggunakan material Heradesign sebesar $307.2 \mathrm{~m}^{2}$.

Penerapan material pada ruang Jazz Club, dikhususkan untuk penggunaan musik Jazz. Pada Jazz Club memiliki volume ruang sebesar $585 \mathrm{~m}^{3}$ sehingga dibutuhkan waktu dengung sebesar 0,6 s. Dari perhitungan waktu dengung, maka dihasilkan kebutuhan material pada ruang Jazz Club yang sudah dilakukan uji dengan Room Calculator akustik dengan dasar DIN 18041. Hasilnya, ruang Jazz Club direncanakan menggunakan Treatment akustik seperti penggunaan plafond berupa Heradesign Baffles $108 \mathrm{~m}^{2}$ dan Thermatex Acoustic seluas 
$102 \mathrm{~m}^{2}$. Pada material lantai menggunakan lantai berbahan linoleum dengan luasan 210 $\mathrm{m}^{2}$. Material pada kursi menggunakan bahan kain sebanyak 70 kursi. Material dinding menggunakan material Heradesign sebesar 27 $\mathrm{m}^{2}$. Material dinding menggunakan material gorden seluas $56 \mathrm{~m}^{2}$.

Pada tingkat volume ruang tertentu, sebuah ruang yang digunakan untuk bermusik Jazz dapat digunakan juga sebagai ruang bermusik Tradisional dengan jangkauan waktu dengung sekitar $0,8-1,2 \mathrm{~s}$ sesuai dengan volume ruangnya. Pada bangunan lain sejenis, sebuah ruang music memungkinkan untuk difungsikan oleh 2 jenis music yang berbeda atau lebih dengan penyesuaian volume ruang dalam mencapai waktu dengung sesuai dengan standard music tersebut. Hal ini juga di dukung dengan pengendalian akustik ruang secara fisik .

\section{REFERENSI}

Aditya, D. Y., Prabowo, B., \& Sumadyo, A. (2015). Solo Musik Dengan Penerapan Sistem Akustik. ARSITEKTURA : Jurnal Ilmiah Arsitektur dan Lingkungan Binaan, 12.

Bentara Budaya Solo. (2018). Retrieved from Komunitas Balai Soedjatmoko Solo: $\mathrm{http} / / / \mathrm{www} \cdot$ bentarabudaya.com/komunit as/balai-soedjatmoko-solo

Dermawan, R. K. (2016). Nge-Jazz Bareng Sri Hanuraga Dan Arini Kumara Di Jazz In Lebaran . Surakarta: Solo Event.

Doelle, L. L. (1990). Akustik Lingkungan. Jakarta: Erlangga.

Edy, C. W. (2019). CATAT! Mangkunegaran Jazz Festival 2019 Digelar Pada 29-30 Maret 2019. Surakarta: Tribun Jateng.

Fitriani, E. (2017). Meriah, Begini Suasana Gelaran Solo City Jazz 2017. Surakarta: Tribun News.

Kartiko, P., Sumaryoto, \& Muqoffa, M. (2018). Penerapan Sistem Akustik pada Ruang Auditorium Balai Sidang di Surakarta. SenTHong, 65-72.

Latifah, N. L. (2015). Fisika Bangunan 2. Jakarta: Griya Kreasi.

Mediastika, C. E. (2005). Akustika Bangunan : Prinsip-prinsip dan Penerapannya di
Indonesia. Yogyakarta: Penerbit Erlangga.

Metta. (2018, November 22). Parkiran Jazz Goes to Campus Tampil Perdana di FISIP UNS. Retrieved 2019, from LPM Visi:

https://www.lpmvisi.com/2018/11/parki ran-jazz-goes-to-campus-tampil.html

Rafiq, A. (2018). Agenda Akhir Pekan Solo: Jazz Mangkunegaran hingga Sala Monolog. Surakarta: Tempo.

Sudarsono, A. S. (2012). Analisis Dan Pengujian Preferensi Akustik Untuk Perancangan Gedung Konser Musik Angklung Pentatonis.

Suharsih. (2018). Ada Solo City Jazz, Jl. Urip Sumoharjo Ditutup 6 Jam Malam Ini. Surakarta: Solo Raya.

Wardhana, Y. W. (2016). Solo Jazz Society 2016 Mengambil Tema Potensi Musisi Muda Lokal. Surakarta: Compusician News. 